\title{
MODELING OF PERFORMANCE AND SAFETY OF A MULTI-TASK UNMANNED AUTONOMOUS MARITIME VEHICLE
MODELOWANIE RUCHU I BEZPIECZEŃSTWA WIELOZADANIOWEGO BEZZALOGOWEGO AUTONOMICZNEGO POJAZDU WODNEGO

\author{
Mirosław K. Gerigk \\ Politechnika Gdańska \\ e-mail:mger@pg.gda.pl
}

\begin{abstract}
At the beginning of the paper the aim of research is presented. Then the method is introduced. Next, the unmanned autonomous maritime vehicle is briefly described. The following chapter concerns a model of vehicle performance including the ballasting and motion. Some information on an integrated steering, positioning and stabilization system of the vehicle is briefly presented in the paper. Such the system enables to obtain a fully autonomous vehicle. In the final part of the paper some issues connected with the risk assessment and assessment of the vehicle safety are introduced.
\end{abstract}

Keywords: unmanned autonomous maritime vehicle (UAMV), performance of $U A M V$ vehicle, safety of UAMV vehicle, precise position stabilization of UAMV vehicle, simulation model

Streszczenie: $W$ początkowej części artykułu przedstawiono cel badań. Następnie, opisano metode badań. Potem, zaprezentowano przedmiot badań: bezzałogowy autonomiczny pojazd wodny. $Z$ kolei, przedstawiono model zachowania sie pojazdu, $w$ tym jego balastowania $i$ ruchu. $W$ artykule przedstawiono wybrane informacje na temat zintegrowanego systemu sterowania, pozycjonowania $i$ stabilizacji pojazdu. Taki system umożliwia otrzymanie $w$ petni autonomicznego pojazdu. W końcowej czessci pracy przedstawiono wybrane problemy zwiazane z ocena ryzyka i bezpieczeństwa pojazdu.

Slowa kluczowe: bezzałogowy autonomiczny pojazd wodny UAMV, ruch pojazdu $U A M V$, bezpieczeństwo pojazdu UAMV, precyzyjna stabilizacja połozenia pojazdu $U A M V$, model symulacyjny 
Modeling of performance and safety of a multi-task unmanned autonomous... Modelowanie ruchu i bezpieczeństwa wielozadaniowego bezzałogowego...

\section{The research}

The contemporary tasks of navy ships require to apply more and more advanced multi-task ships. Those ships are very often the platforms for the unmanned air vehicles (UAV) and unmanned maritime vehicles (UMV) including the surface and underwater vehicles. The unmanned maritime vehicles may either be the remote operated vehicles or unmanned autonomous vehicles.

In the paper the problems presented are mainly connected with the unmanned autonomous underwater and surface vehicles.

The primary task of such the vehicle should be to conduct a mission when the acquired information would directly be processed and used including sending this information to the command centre.

The main objective of the current research is to work out a functional model of an advanced vehicle which should be able to move on the water surface with a different range of speed. The second aim is to achieve a possibility to move the vehicle above the water surface for a short period of time. The flight height should be less than 3 meters. The vehicle should have a special power system supply enabling the vehicle to work for at least 30 minutes. The sleeping mode of the vehicle has been assumed of up to a few hours before the new energy supply.

The methodology research is based on the holistic approach to the design, construction and operational problems. The research problems associated with development of a concept of the vehicle moving in two specific operational conditions are associated with the following tasks: vehicle definition, assessment of vehicle performance, vehicle steering and control, safety assessment of the vehicle. The vehicle is defined as a hybrid-mono-hull including the hull form and arrangement of internal spaces.

The estimation of the vehicle mass is connected with calculation of the following weights:

- weight of the skin plates, main frames, etc.,

- weight of the propulsion system,

- weight of all the sub-systems and equipment,

- weight of the payload.

Then the vehicle performance may be assessed. First of all this is connected with estimation of the floatability, stability, resistance and propulsion characteristics. Then the steering and control characteristics are estimated due to assessment of the maneuverability and seakeeping characteristics.

The performance assessment should be followed by the risk assessment. The assessment of the vehicle performance and risk assessment should be done for the data operational conditions and sequence of events under consideration. After that the safety assessment of the vehicle may be done.

The concept of the vehicle is investigated by the author since 2010. Some parts of the latest work on the vehicle development require an advanced research carried out by the author and a team of specialists from a few Polish research institutions $[1,2,8,10]$. 


\section{A research and design method}

The method is a kind of performance-oriented risk-based method which enables to assess the vehicle performance and safety at the design stage and in operation. The method takes into account the influence of design and operational factors on the vehicle performance and safety including the safety management related factors. The holistic approach to the safety assessment of the vehicle is applied. The method is based on implementation of the system approach to safety.

For assessment of the vehicle performance the investigations using the physical models and numerical simulation techniques may be applied. This analysis enables to take into account the influence of the intermediate events, additional events (releases) and consequences on the vehicle behavior. This may be done for the data sequence of events and for a scenario under consideration.

The risk assessment is based on application of the matrix type risk model which is prepared in such a way that it enables to consider almost all the scenarios of events. The criteria within the method is to achieve an adequate level of risk using the risk acceptance criteria (risk matrix). Providing a sufficient level of safety based on the risk assessment is the main objective. It is either the design, operational or organizational objective. Safety is a design objective between the other objectives. The measure of safety of the vehicle is the risk (level of risk).

The method is based on the following main steps:

- setting the requirements, criteria, limitations, safety objectives;

- defining the vehicle and environment;

- identifying the hazards and identifying the sequences of events (scenarios);

- assessing the vehicle performance;

- estimating the risk according to the event tree analysis ETA and matrix type risk model (risk is estimated for each scenario separately);

- assessing the risk according to the risk acceptance criteria (risk matrix) and safety objectives;

- managing the risk according to the risk control options;

- selecting the design (or operational procedure) that meet the requirements, criteria, limitations, safety objectives;

- optimizing the design (or operational procedure);

- making the decisions on safety.

The general structure of the method from the research and design point of view is presented in Figure $1[1,2,6,8,10]$. 


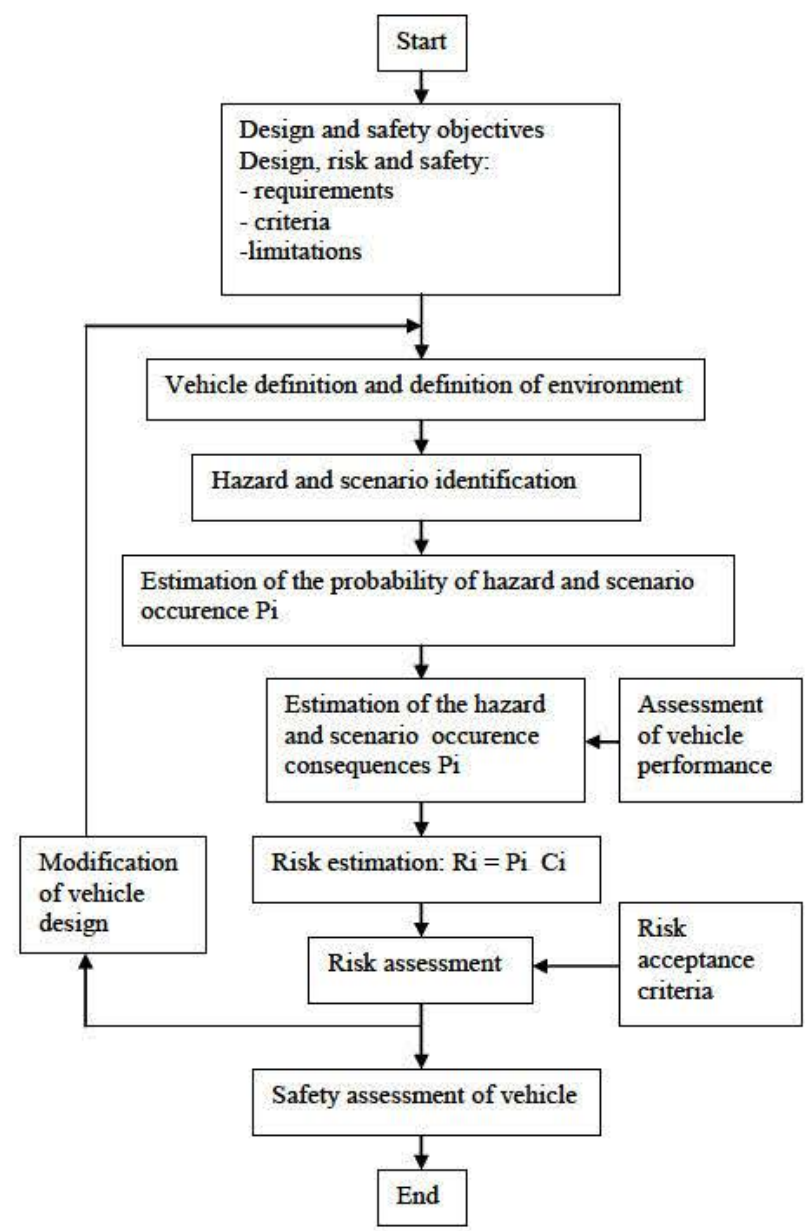

Fig. 1 Structure of the method of risk and safety assessment of ships and maritime objects.

\section{The unmanned autonomous maritime vehicle UAMV}

The primary aim of the research is to work out a functional model of the vehicle moving in two specific operational conditions. The operational conditions are related to the tasks the vehicle is designed for.

The novel solutions have been applied regarding the vehicle hull form, arrangement of internal spaces, materials and propulsion system. The final hull form is a combined "planning - wing in ground" form. The basic arrangement of internal spaces has been designed according to functional requirements. The arrangement of the vehicle internal spaces is very much affected by the subsystems to be installed. 
The sub-systems which have been taken into account are as follows:

- air-jet conventional propulsion sub-system,

- water-jet propulsion sub-system,

- main power supply sub-system,

- ballast sub-system,

- air supply sub-system,

- energy supply and general electrical sub-system,

- steering and control sub-system,

- communication and navigation sub-system

- multi-task patrol sub-system or combat sub-system.

The stealth technology achievements have been applied to obtain the unique hydrodynamic and other characteristics. The major factors enabling obtaining the vehicle stealth features are: hull form, hull skin cover, modified boundary layer, modified emission of vibrations and acoustic (hydro-acoustic) space.

It has been anticipated that the vehicle may have a possibility to move on the water surface and for a short time above the water surface. The flight height is small and it is assumed to be less than 3 meters. A physical model No.2 and visualization of the third version of the vehicle design under consideration is presented in Figure 2.
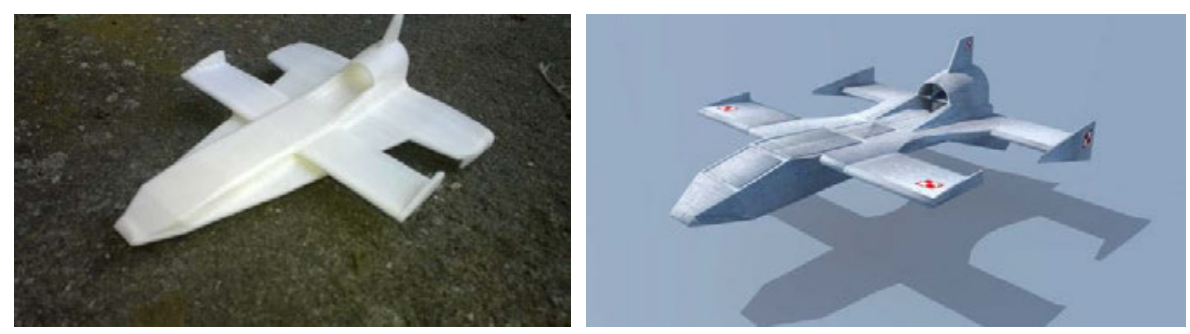

Fig. 2 A physical model No. 2 and visualization of the third version of the UAMV design (by M.K. Gerigk, 2011-2015).

The third version of the vehicle design has the main parameters as follows:

- overall length $\mathrm{L}$ - is equal to 5.8 meters,

- operational breadth B - is equal to 5.2 meters or 6.0 meters, depending on the wing system applied,

- breadth during transport $\mathrm{B}_{\mathrm{t}}$ - is equal to 2.4 meters,

- height $\mathrm{H}$ - is equal to 1.1 meters,

- mass is equal to from 1.8 tons to 2.4 tons, depending on the weight of equipment installed,

- maximum object speed on the water surface $\mathrm{v}_{\mathrm{ws}}$ - is equal to 15 meters/seconds,

- maximum object speed above the water surface $\mathrm{V}_{\mathrm{aws}}$ - is equal to from 15 meters/seconds to 45 meters/seconds, depending on the air-jet propulsion and wing system applied. 
Modeling of performance and safety of a multi-task unmanned autonomous... Modelowanie ruchu i bezpieczeństwa wielozadaniowego bezzałogowego...

A visualization of a more advanced version of the UAMV vehicle under research is presented in Figure 3.

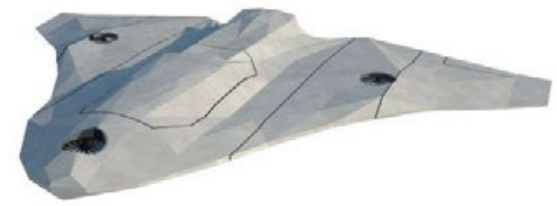

Fig. 3 A visualization an advanced version of the UAMV vehicle (by M.K. Gerigk, 2011-2015).

\section{The performance assessment of the UAMV vehicle}

\section{Ballasting}

During the ballasting process the dynamic stability of the vehicle should be permanently controlled. It is very important to know the locations of the vehicle centre of gravity and centre of buoyancy in each step time.

On the water surface the restoring moment $M_{R}$ (transversal or longitudinal) of the vehicle at small changes of heel is composed of the moment due to the vehicle buoyancy and moment due to the vehicle weight $[3,6]$ :

where:

$$
M_{R}=M_{B}+M_{W}
$$

$M_{B}$ - moment due to the vehicle buoyancy, $M_{B}=V \rho g Z_{\text {quasi-static }}$,

$\mathrm{V}$ - immersed buoyancy of the vehicle,

$\rho$ - density of water,

g - gravity acceleration,

$\mathrm{GZ}_{\text {quasi-static }}$ - righting arm of buoyancy for the quasi-static condition at each buoyancy increase and time step,

$\mathrm{M}_{\mathrm{B}}$ - moment due to the vehicle weight, $\mathrm{M}_{\mathrm{W}}=\sum\left(\rho \mathrm{g} \Delta \mathrm{V}_{\mathrm{Ti}}\right) \mathrm{r}_{\mathrm{i}}$,

$\Delta \mathrm{V}_{\mathrm{Ti}}$ - volume of ballast water in the ballast tank under consideration,

$r_{i} \quad$ - heeling arm following from the ballast water in the data ballast tank.

\section{Motion}

The general set of equations of the UAMV vehicle moving on the water surface (for the different phases of motion) may be presented as follows [3-6]:

$$
\sum_{j=2}^{6}\left(M_{i j}+A_{i j}\right) \ddot{x}_{j}(t)+B_{i j} \dot{x}_{j}(t)+C_{i j} x_{j}(t)=\sum_{j=2}^{6} F_{i j}(t)
$$

where:

i - index of the data component of the vehicle motion $(i=2, \ldots, 6)$,

j - index of the data degree of freedom,

$\mathrm{M}_{\mathrm{ij}}$ - vehicle mass matrix,

$\mathrm{A}_{\mathrm{ij}}$ - matrix of added masses,

$B_{i j}$ - matrix of dumping coefficients,

$\mathrm{C}_{\mathrm{ij}}$ - matrix of restoring coefficients,

$\mathrm{F}_{\mathrm{ij}}$ - matrix of external hydrodynamic and aerodynamic forces. 
At the current stage of research the following impacts have been taken into account:

- gravity forces,

- hydrodynamic restoring forces,

- hydrodynamic Froude-Krylov and diffraction forces,

- hydrodynamic slamming based forces,

- hydrodynamic and aerodynamic lift forces,

- hydro and aerodynamic cushion forces (wing in ground forces),

- thrust forces.

\section{A precise position stabilization system PPSS}

The autonomous underwater vehicles perform locomotion and manipulation tasks that require a high precision positioning. The precise position stabilization system PPSS operates independently of the main drive and this is responsible for the navigation unit. The PPSS system has a separate electric executive motors. The electric drive allows to work in the conditions of immersion and to charge unattended. Having a model of the PPSS system the designers are able to determine the extent of the vehicle and track energy usage during the mission $[6,7,8,9]$.

One of the main research and design issues is to work out a precise position stabilization system PPSS for the UAMV vehicle. This system is independent from the main propulsion system which is responsible for the vehicle motion controlled by the navigation system. The main propulsion system and PPSS system have the acting electrical engines. The electric propulsion enables the vehicle to work during the submersible mode and automatic energy uploading.

It is possible to upload the batteries using the installed photovoltaic batteries. The underwater mobile uploading stands may cause that the vehicle is able to stay submerged without limitations.

The PPSS system should be treated as a separate module because the activity of the vehicle connected with collecting the species, detecting the objects, scanning the sea bottom, geometry measurements of the surrounding environment using the tools installed onboard the vehicle require a precise determination and keeping the vehicle position and orientation.

It has been mentioned that besides of the main propulsion system the vehicle has a system of precise positioning. As an example this system may consists of four thrusters located horizontally or vertically to the vehicle base plane. The system should enable to obtain the required position of the vehicle. The position in $3 \mathrm{D}$ space is determined by the $\mathrm{N}_{\mathrm{H}} \mathrm{i} \mathrm{O}$ vectors including point $\mathrm{p}_{1}$ or by the plane $\mathrm{H}$ and points $\mathrm{p}_{1}$ and $\mathrm{p}_{2}$. The position of the PPSS system thrusters according to the vehicle base plane is presented in Figure $4[6,7,8,9]$. 


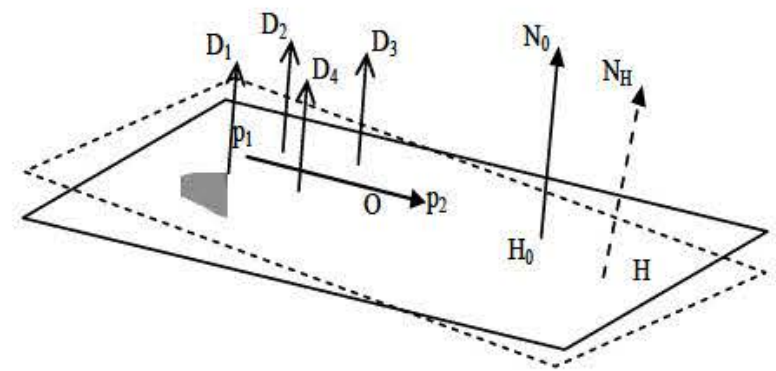

Fig. 4 The position of the PPSS thrusters according to the vehicle base plane.

The physical model consists of the geometrical position of the precise propulsion units, formal description of the sensor system, AI system for analyzing the data and system of effectors.

Four thrusters located symmetrically according to the vehicle centre plane are installed in such a way that the thrust vectors may be perpendicular to the vehicle base plane if required. The vehicle motion may be obtained using and steering the rotational speed of four the thrusters in the same time.

For the modeling purposes for the small values of vehicle speed during the precise positioning the geometrical position of the precise propulsion units is very important as it is shown in Figures 5 and $6[6,7,8,9]$.

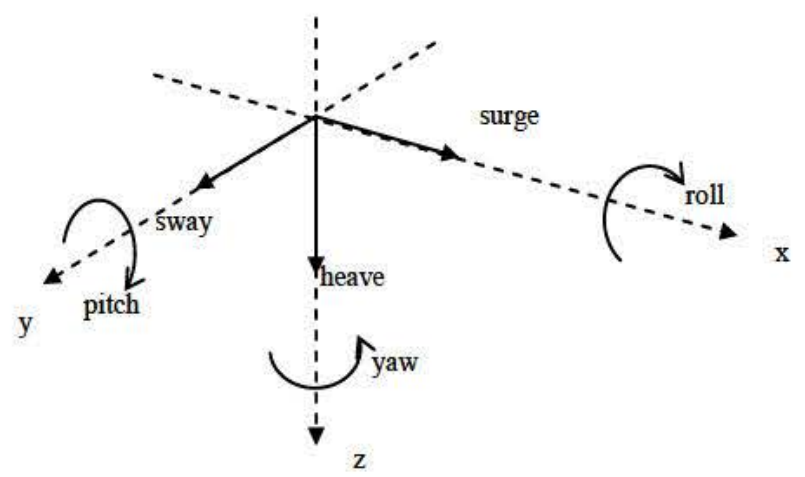

Fig. 5 A standard model using $6 \mathrm{DoF}$

The 6 DOF (degree-of-freedom) model including the linear u,v,w (surge, sway, heave) and angular p, q, r ( roll, pitch, yaw) velocities is the base for predicting the seakeeping characteristics of the vehicle. The relative position to the sea bottom (or GPS coordinates) is in the form of the vector of the position $\mathrm{x}, \mathrm{y}, \mathrm{z}$ and Euler angles $\varphi, \theta, \psi$. 


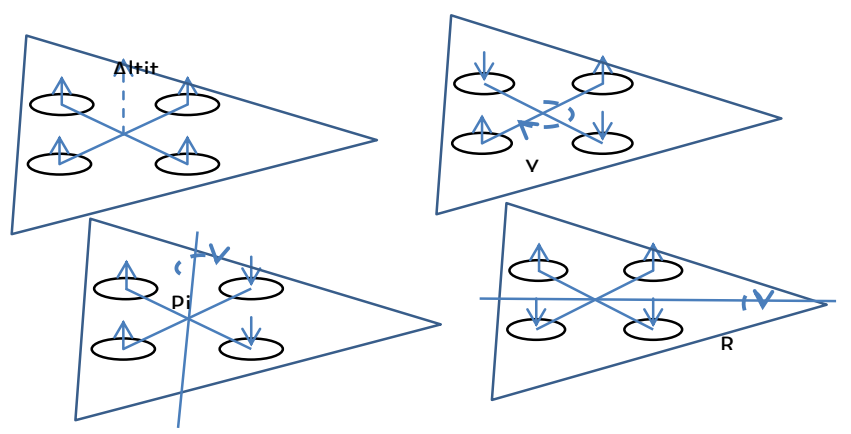

Fig. 6 The vectors of the precise propulsion units during the positioning of the vehicle.

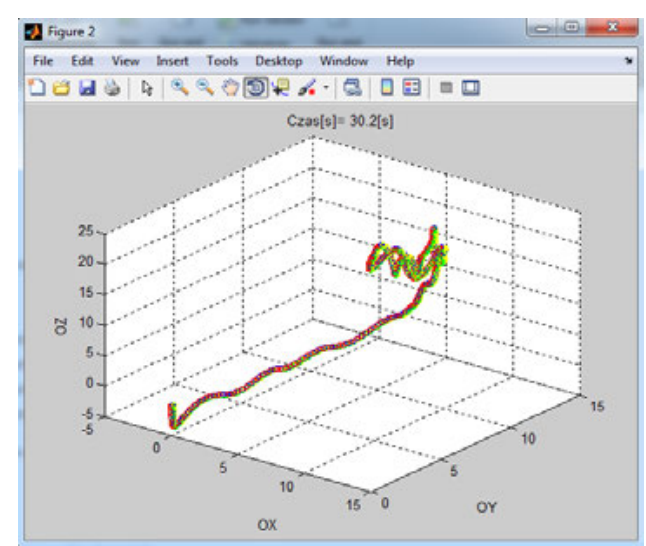

Fig. 7 The preliminary results of computer simulation of the PPSS system work.

The computational model for the vehicle motion prediction has been prepared using the Matlab environment. There are six main interrelated modules. It is possible to put in the preliminary and final position of the vehicle, thrust of the propeller (rotational speed) and expected impacts (current). A general view of the preliminary results of the computer simulation of the PPSS system work is presented in Figure 7 [6, 7, 8, 9].

\section{The risk assessment and assessment of the vehicle safety}

The risk model associated with the different hazards and scenarios should be estimated according to the well known general formulae:

where:

$$
\mathrm{R}_{\mathrm{i}}=\mathrm{P}_{\mathrm{i}} \times \mathrm{C}_{\mathrm{i}}
$$

$P_{i}$ - probability of occurrence of a given hazard;

$\mathrm{C}_{\mathrm{i}}$ - consequences following the occurrence of the data hazard and scenario development. 
Modeling of performance and safety of a multi-task unmanned autonomous... Modelowanie ruchu i bezpieczeństwa wielozadaniowego bezzałogowego...

In the case of the UAMV vehicle a general formulae for estimating the risk depending on a hazard occurred may be presented as follows:

$$
\mathrm{R}_{\mathrm{i}}=\mathrm{P}_{\mathrm{HO}} \mathrm{P}_{\mathrm{SD} / \mathrm{HO}}\left(1-\mathrm{P}_{\mathrm{SNSS}}\right) \mathrm{C}
$$

where:

$\mathrm{P}_{\mathrm{HO}}$ - probability of the data hazard occurrence,

$\mathrm{P}_{\mathrm{SD} / \mathrm{HO}}$ - probability of the data scenario development conditional on the data hazard occurrence,

$\mathrm{P}_{\mathrm{SNSS}}$ - probability of UAMV vehicle survival conditional on the data scenario development and conditional on the data hazard occurrence,

$\mathrm{C}$ - consequences regarding the fatalities $\mathrm{C}_{\mathrm{HF}}$ ( $\mathrm{HF}$ - Human Factor), property (vehicle), environment $\mathrm{C}_{\mathrm{E}}$ ( $\mathrm{E}$ - Environment), estimated at each stage of an accident (catastrophe).

A major hazard taken into account during the research is the killability of the UAMV vehicle under consideration. The probability of the data hazard occurrence, probability of the vehicle killability may be written as follows:

where:

$$
\mathrm{P}_{\mathrm{HO}}=\mathrm{P}_{\mathrm{K}}=\mathrm{P}_{\mathrm{S}} \mathrm{P}_{\mathrm{K} / \mathrm{S}}
$$

$\mathrm{P}_{\mathrm{K}}$ - probability of the vehicle killability,

$P_{S}$ - probability of the vehicle susceptibility,

$\mathrm{P}_{\mathrm{K} / \mathrm{S}}$ - conditional probability vulnerability in the case of the vehicle damage.

The probability of the vehicle susceptibility $P_{S}$ is the measure of the vehicle inability to intercept any of the threats: detecting, classifying, targeting, attacking or hitting. The key issue from the interception point of view are the stealth features the vehicle may possess.

The probability $\mathrm{P}_{\mathrm{SNSS}}$ may be estimated using the following methods: binary method, method based on definition of the vehicle hydrostatic and aerostatic characteristics, method based on definition of the vehicle performance.

In the case of the last method the sway, heave, roll and pitch functions in time domain have been anticipated as the major characteristics enabling the risk assessment for the UAMV vehicle. The risk analysis requires to estimate the conditional probabilities concerning the major events (initial events, hazards), intermediate events and final events (consequences). The risk model should be developed using the event tree analysis ETA in such a way that it would be possible to consider as many scenarios as possible [6].

\section{Conclusions}

The preliminary results concerning the development of the UAMV vehicle concept including the main parameters, geometry, weights estimation, vehicle performance and risk assessment have been presented in the paper.

The autonomous underwater vehicles perform the motion and manipulation tasks that require the high precision positioning. 
The preliminary results concerning the precise position stabilization system PPSS that ensures the stabilization of the position and the correct orientation have been obtained.

It has been assumed that the PPSS system operates independently of the main drive having a separate electric executive motors. The electric drive allows to work in conditions of immersion and to charge unattended.

Some investigations have been done using a simulation model of the vehicle movements during the planned mission. The simulation program allows to check the operation of algorithms of each component. It enables to move the vehicle due to the influence of interference as well. The designers may use the model to determine the extent of the vehicle and track energy usage during the mission.

At the current stage of research the following tasks have been performed: functionality of PPSS system, physical model of PPSS system, computer simulation of PPSS system.

\section{Bibliography}

[1] AUVSI/ONR Engineering Primer Document for the Autonomous Underwater Vehicle (AUV) Team Competition Association for Unmanned Vehicle Systems International (AUVSI) US Navy Office of Naval Research (ONR), Version 01 - July 2007.

[2] Cwojdziński L., Gerigk M.K. Polskie innowacyjne rozwiązania w zakresie jednostek i obiektów morskich, w tym systemów bezzałogowych. Nowa Technika Wojskowa, nr 11, 2014.

[3] Dudziak J.: Teoria okrętu, Fundacja Promocji Przemysłu Okrętowego i Gospodarki Morskiej, Gdańsk 2008.

[4] Faltinsen O.M.: Sea Loads on Ships and Offshore Structures, Cambridge University Press, 1990.

[5] Faltinsen O.M. : Hydrodynamics of High-Speed Marine Vehicles, Norwegian University of Science and Technology, Cambridge University Press, 2005.

[6] Gerigk M.K.: Kompleksowa metoda oceny bezpieczeństwa statku w stanie uszkodzonym z uwzględnieniem analizy ryzyka, Monografie 101, Wydawnictwo Politechniki Gdańskiej, Gdańsk 2010.

[7] Gerigk M.K., Wójtowicz S.: Model systemu sterowania małego obiektu bezzałogowego poruszającego się na powierzchni wody, Logistyka $2014 \mathrm{nr} 6$.

[8] Gerigk M.K.: Innowacyjne wielozadaniowe jednostki i obiekty pływające dla komponentu morskiego sił zbrojnych RP, The Manual, 11th International Conference \& Exhibition "Advanced Technologies for Homeland Defense and Border Protection". Zarząd Targów Warszawskich S.A., Intercontinental Hotel, Warsaw, 14th May 2015. 
Modeling of performance and safety of a multi-task unmanned autonomous...

Modelowanie ruchu i bezpieczeństwa wielozadaniowego bezzałogowego...

[9] Gerigk M.K., Wójtowicz S., Zawistowski M.: Precyzyjny system stabilizacji pozycji autonomicznego pojazdu podwodnego do celów specjalnych, Logistyka - nauka, nr 3, 2015.

[10] Lamb. G.R.t High-speed, small naval vessel technology development plan, Total Ship Systems Directorate Technology Projection Report, NSWCCD-20TR-2003/09, Carderock Division, Naval Surface Warfare Center, Bethesda, MD 20817-5700, May 2003.

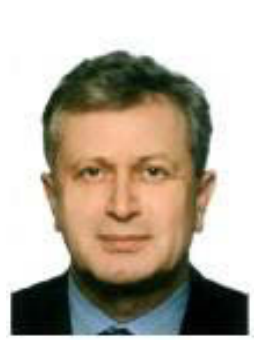

D.Sc Eng. Mirostaw K. Gerigk was graduated from the Technical University of Gdańsk in 1984 and obtained his Dr. Eng. (Ph.D.) degree at the same University in 1990. He obtained his D.Sc. degree at the Faculty of Transport, Warsaw University of Technology in 2011. In 2015 he became a Professor of the Gdańsk University of Technology. His research activity concerns the theory of ships, ship hydrodynamics, innovative maritime craft design, design of unmanned autonomous maritime vehicles, theory of safety, safety of ships and safety at sea. 